\title{
Estimation of the life cycle cost of the upper railway track structure
}

\author{
Nikolai Karpuschenko ${ }^{1, *}$, and Pavel Trukhanov ${ }^{1}$ \\ ${ }^{1}$ Siberian Transport University, 630049 Novosibirsk, Russia
}

\begin{abstract}
The length of tracks with excess tonnage was $14 \%$ in the territory of the Russian Federation in 2007, and it reached $20 \%$ by 2017 . Removal of these restrictions is possible due to modernization of the upper railway track structure (URTS) with increasing its durability and lowering of the life cycle cost (LCC). The purpose of the study is building the LCC estimation model. This model includes the structure of the URTS, the categories and elements of the costs for its maintenance, identification (estimation) of costs, algorithms for their calculation. The average annual LCC of $1 \mathrm{~km}$ of the URTS includes the cost of reconstruction, maintenance, intermediate repairs, elimination of consequences of road failures and disposal in the form of the return value of old URS elements. The developed methodology was tested on the actual data of one of the sections of the West Siberian Infrastructure Directorate. The analysis of the obtained data made it possible to conclude that the adopted model of calculating the LCC of URTS adequately displays the categories and elements of the costs for maintenance of the railway track, their specific share in the LCC.
\end{abstract}

\section{Introduction}

Efficiency of a railway track as a railway transport infrastructure facility is determined by the level of reliability (failure-free operation, durability) and the cost of ownership (operation). Existing safety requirements affect the life cycle cost, as they determine the capacity and the type of the structure, norms and tolerances of railway track parameters in designing of maintenance [1]. In this regard, the subject of the study is a methodological tool for estimating the efficiency of design solutions for selection of the railway track design, its maintenance and life cycle duration.

The focus of this article is justification of the life cycle cost model of the upper railway structure, including the following: determining the facility structure (decomposition of the railway structure), selecting the category and cost elements for its modernization and maintenance, as well as presentation of costs.

The management system for the railway transport infrastructure technical condition is based on a concept that includes a set of risk management, resource management, reliability analysis (RRMRA) methods, estimation of the remaining resource (service life) of infrastructure facilities in operation and maintenance $[2,3]$. In particular, this is due to the

\footnotetext{
*Corresponding author: pavelst07@mail.ru
} 
requirements of the RAMS safety ensuring system and a number of European and Russian standards [4-6]. Existing traffic safety requirements significantly affect the life cycle cost when designing and maintaining the railway track [1].

The peculiarity of the research problem of calculating the LCC of railway infrastructure facilities is the complexity of determining the costs for the railway track maintenance. The review of foreign studies [7] performed earlier showed that they did not fully correspond to the conditions of the Russian railways, primarily in the field of maintenance of the URTS. Publications of Russian authors $[8,9]$ are general approaches to estimation of the LLC of innovative railway track designs and do not contain specific data on the categories and elements of the costs for the LCC and their identification methods.

In this connection, the essence of this study is development of a methodology, building a cost model and an algorithm for calculating the life cycle cost of the upper railway track structure. This represents the research novelty of this paper. In addition, new methods are private methods for determining the cost elements for the current road maintenance, elimination of railway track failures. These methods are developed on the basis of an array of statistical data obtained from the software package of the Russian Railways JSC, i.e., the Unified Corporate Automated Infrastructure Management System (UCAIMS). The empirical dependencies built on this basis take into consideration the specifics of operating conditions, development of tonnage and railway track failures in the track sections under consideration.

\section{Research method}

The life cycle cost (LCC) is the total cost of the facility during its entire life cycle. The main purpose of the LCC calculation is to provide input for making cost-effective decisions in the field of investment, renovation and maintenance of the railway infrastructure facility. Since the LCC analysis is presented as assistance for solutions of the reconstruction design, maintenance, etc., its use should be limited to the costs that can be controlled. To do this, it is necessary to identify the factors that affect the URTS operation and their interrelations $[10,11]$.

The LCC calculation process includes definition and estimation of the costs associated with development, acquisition (production), ownership and disposal of the facility during its life cycle. The LCC shall be calculated as the sum of its costs $[12,13]$ :

$$
L C C=C_{\text {development }}+C_{\text {production }}+C_{\text {ownership }}+C_{\text {disposal }}
$$

Cost elements are interrelations between the categories of costs and the facility structure by elements. This approach has the advantage, which manifests itself in the system and the exact method and provides a high level of confidence in the fact that all cost elements have been taken into consideration. In connection with this, let us adopt the following cost model:

$$
\left\{\begin{array}{l}
\overline{\mathrm{LCC}}=\frac{S_{\mathrm{rec}}+\sum_{i=1}^{n}\left(S_{\text {upkeep }}(i)+S_{\mathrm{r}}(i)+S_{\text {fail }}(i)\right)-S_{\mathrm{disp}}(n)}{n} \rightarrow \mathrm{min} ; \\
\eta(n) \leq C,
\end{array}\right.
$$

Where $\overline{\mathrm{LCC}}$ is the average annual life cycle cost of $1 \mathrm{~km}$ of the URTS, thousand rubles; $S_{\text {rec }}$ is the reconstructions cost (RC), thousand rubles; $S_{\text {upkeep }}(i)$ is the cost of current upkeep per year $i$, thousand rubles; $S_{\mathrm{p}}(i)$ is the cost of intermediate repairs per year $i$, thousand rubles; $S_{\text {fail }}(i)$ is the cost of failures per year $i$, thousand rubles; $S_{\text {disp }}(n)$ is the cost of facility 
disposal (at the end of the service life), thousand rubles; $n$ is the life cycle duration in years, thousand rubles; $\eta$ is the function of failures *(reliability indicator); $C$ is the required reliability method.

The sum of initial costs and reduced operating costs (taking into consideration the distance to the $\eta=\frac{1}{(1+d)^{i}}$ coefficient that is most recent) for the compared options can be represented with the following expression:

$$
\mathrm{LCC}=S_{\mathrm{rec}}+\sum_{i=1}^{n} \frac{S_{\mathrm{upkeep}}(i)}{(1+d)^{i}}+\sum_{i=1}^{n} \frac{S_{\mathrm{r}}(i)}{(1+d)^{i}}+\sum_{i=1}^{n} \frac{S_{\mathrm{fail}}(i)}{(1+d)^{i}}+\frac{S_{\mathrm{disp}}(n)}{(1+d)^{i}},
$$

where LCC is the life cycle cost of $1 \mathrm{~km}$ of the railway track for the entire services life, thousand rubles; $d$ is the discounting rate; $i$ is the year of making costs.

Life cycle cost model. The life cycle of the railway track structure begins with reconstruction (or enhanced overhaul). Then, intermediate repairs are performed: average, continuous replacement of rails with the works in the scope of average repair, lifting repair, scheduled preventive repair. Grinding is also performed with certain frequency and continuous replacement of rails is performed depending on their condition (Fig.1). At the end of the life cycle, the railway track is recycled with a return value. Then, the second reconstruction (or major overhaul) is performed, which is the beginning of the life cycle of the newly laid track structure.

$\mathrm{R}$

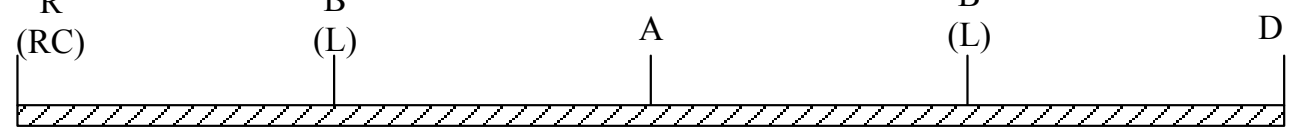

continuous replacement and grinding of rails

Fig. 1. Rehabilitation works performed during the railway track life cycle: $\mathrm{R}$ is track reconstruction; $\mathrm{RC}$ is enhanced overhaul; $\mathrm{A}$ is the average repair; $\mathrm{B}$ is scheduled preventive repair; $\mathrm{L}$ is lifting repair; $\mathrm{D}$ is the URTS disposal.

\section{Cost elements calculation}

The data for the LCC calculates has been taken from the UCAIMS of the West Siberian Infrastructure Directorate for 2017, after which it has been processed in accordance with the method made up.

Railway track reconstruction cost. According to the details of the track service of the West Siberian Infrastructure Directorate for 2017, the cost of reconstruction of the railway track with consideration of the cost of designing per $1 \mathrm{~km}$ comprises $S_{\text {rec }}=23$ to 26 million rubles depending on the track section parameters.

Cost of current track upkeep. It is to be determined by the following formula

$$
S_{\text {upkeep }}(i)=S_{\mathrm{op}}(i)+S_{\mathrm{m}}(i)+S_{\text {mech }}(i), \text { thousand rubles }
$$

where $S_{\mathrm{op}}(i)$ is the costs for remuneration of labor, deductions, and special clothes of the workers involved in the current railway track upkeep, thousand rubles; $S_{\mathrm{rm}}(i)$ is the costs for replacement of the upper railway track structure materials, thousand rubles; $S_{\text {mech }}(i)$ is the costs associated with operation of machines and mechanisms, thousand rubles.

Costs $S_{\mathrm{op}}(i)$ for remuneration of labor, deductions, and special clothes of the workers involved in the current railway track upkeep shall be determined by the following formula 


$$
S_{\mathrm{op}}(i)=T+B+K_{\mathrm{r}}+D S N+O+C, \text { thousand rubles }
$$

where $T$ is the annual tariff for remuneration of labor of the $3^{\text {rd }}$ category workers that lay the track, thousand rubles; $B$ is the bonus to the wage, thousand rubles; $K_{\mathrm{r}}$ is consideration of the district factor, thousand rubles; $D S N$ is deductions for social needs, thousand rubles; $O$ is overhead costs, thousand rubles; $C$ is the cost of special clothes, thousand rubles.

Calculation of the components of formula (5) shall be performed according to the following algorithm.

Annual tariff for remuneration of labor of the $3^{\text {rd }}$ category workers that lay the track Tariff $=($ labor costs) $x$ (hourly tariff rate), thousand rubles.

According to the method of calculation of labor costs with the district system of the current track upkeep [12], the calculation of labor costs for the railway track distance shall be performed assuming 2017 as the beginning of the life cycle of the upper railway track structure after reconstruction. The workload in the following years is planned based on the growth of the missed tonnage by the amount of freight traffic, which determines the accumulated tonnage for the year. Operating conditions and rail track design are permanent and adopted as of 01.01.2017.

To determine the labor cost for the current upkeep of the track, the authors introduce the concept of a reference kilometer [14].

Reference kilometer for a seamless track: a continuous track, rails of the P-65 type of unlimited length, reinforced concrete sleepers, KB type fasteners, crushed stone ballast; a section of the track equipped with automatic blocking, located at sites and inclines not steeper than $8 \%$, in straight or curved radii of more than $800 \mathrm{~m}$; freight traffic is 26 to 50 million gross tons $/ \mathrm{km}$ per year; passed tonnage is 201 to 400 million gross tons; trains speeds: 101 to $120 \mathrm{~km} / \mathrm{h}$ for passenger trains / 81 to $90 \mathrm{~km} / \mathrm{h}$ for freight trains.

With the help of regression analysis [14], the equations of dependencies of the labor cost norms of the workers involved in the current upkeep of the seamless path, in persons/year, on load-bearing capacity $\mathrm{G}$, in million gross tons $/ \mathrm{km}$ per year and tonnage $\mathrm{T}$, million gross tons.

$$
N_{b}=0,055+2,7 \cdot 10^{-3} G+2,2 \cdot 10^{-4} T, \text { pers. } / \text { year }
$$

The influence of structural peculiarities of the seamless structure on the labor cost norms is taken into consideration by the adjustment factors in accordance with [14].

Expenses for one-time replacement of materials of $1 \mathbf{~ k m}$ of the upper railway track structure. These costs shall be determined with the method represented in work [15]. Besides, the method contains parameters of the regression dependence of expenditure of materials

$$
N_{\mathrm{b}}=a+b G+c \mathrm{~T}
$$

where $a, b$ and $c$ are the parameters with the units of measurement in pers./year, pers./(million $\mathrm{t} \cdot \mathrm{km}$ (gross) $/ \mathrm{km}$ per year) and pers./million gross tons; $\mathrm{G}$ and $\mathrm{T}$ are loadintensity, million $\mathrm{t} \cdot \mathrm{km}$ (gross) $/ \mathrm{km}$ per year and passed tonnage, million gross tons.

See the total cost of the current upkeep of $1 \mathrm{~km}$ of a seamless track per year in Table 1. 
Table 1. The aggregate costs for the current upkeep of $1 \mathrm{~km}$ of the seamless track ( 1 track, $\mathrm{G}=115$ million $\mathrm{t} \cdot \mathrm{km}$ (gross) $/ \mathrm{km}$ per year).

\begin{tabular}{|c|c|c|c|c|c|c|c|}
\hline Number of years of the LC & 0 & 1 & 2 & 3 & 4 & 5 & 6 \\
\hline Year & 2017 & 2018 & 2019 & 2020 & 2021 & 2022 & 2023 \\
\hline Tonnage, million gross tons & 58 & 173 & 288 & 403 & 518 & 633 & 691 \\
\hline $\begin{array}{c}\text { Remuneration of labor, } \\
\text { deductions, and special clothes, } \\
\text { thousand rubles }\end{array}$ & 197.5 & 407.0 & 408.9 & 409.1 & 430.8 & 451.8 & 231.3 \\
\hline $\begin{array}{c}\text { Cost of materials, } \\
\text { thousand rubles }\end{array}$ & 133.3 & 279.6 & 305.1 & 330.6 & 356.1 & 381.6 & 197.2 \\
\hline Total, thousand rubles & 330.8 & 686.6 & 714.0 & 739.7 & 786.9 & 833.4 & 428.5 \\
\hline
\end{tabular}

Track failures costs. The costs associated with elimination of the upper railway track structure failures $S_{\text {fail }}(i)$ include the costs for acceleration and deceleration of trains due to reduction in movement speeds $S_{\mathrm{ss}}$ and the costs of the trains idle time during a "window" $S_{\mathrm{w}}$

$$
S_{\text {fail }}(i)=S_{\mathrm{ss}}+S_{\mathrm{w}}
$$

\section{Result of the life cycle cost research}

Let us calculate the LCC in accordance with the aforementioned procedure. The calculation is performed in the $3-\mathrm{A}$ direction on a double-track section of the Central Siberian Railway, which has a complex layout and profile. The first and the second track differ in load-intensity by three times. As the first track has a high freight intensity and a short service life, two variants of repairs are considered along this track: according to the classical scheme (option 1) and with the continuous replacement of rails and straightening of the track in the scope of works of an average repair in the middle of the life cycle (option 2) to extend the life cycle. The final results of the LCC calculation can be found in Table 2 and in Figure 2.

Table 2. Total costs for maintenance and repair of $1 \mathrm{~km}$ of the track for the life cycle period.

\begin{tabular}{|c|c|c|c|c|c|c|c|}
\hline \multirow{3}{*}{ No. } & \multirow{3}{*}{ Type of costs } & \multicolumn{6}{|c|}{ Cost } \\
\hline & & \multicolumn{2}{|c|}{ track 1 (option 1) } & \multicolumn{2}{|c|}{ track 1 (option 2) } & \multicolumn{2}{|c|}{ track 2} \\
\hline & & $\begin{array}{c}\text { thousand } \\
\text { rubles }\end{array}$ & percent & $\begin{array}{c}\text { thousand } \\
\text { rubles }\end{array}$ & percent & $\begin{array}{c}\text { thousand } \\
\text { rubles }\end{array}$ & percent \\
\hline 1 & Reconstruction & 25,000 & 65.9 & 25,000 & 40.2 & 25,000 & 63.1 \\
\hline 2 & $\begin{array}{l}\text { Intermediate } \\
\text { repairs and } \\
\text { disposal }\end{array}$ & 5,966 & 15.7 & 22,242 & 35.7 & 7,466 & 18.8 \\
\hline 3 & Current upkeep & 4,520 & 11.9 & 10,004 & 16.1 & 5,356 & 13.5 \\
\hline 4 & $\begin{array}{l}\text { Continuous } \\
\text { replacement } \\
\text { and grinding of } \\
\text { rails }\end{array}$ & 2,069 & 5.5 & 4,139 & 6.7 & 1,176 & 3.0 \\
\hline 5 & Track failures & 392 & 1.0 & 784 & 1.3 & 652 & 1.6 \\
\hline & Total & 37,947 & 100 & 62,169 & 100 & 39,650 & 100 \\
\hline
\end{tabular}




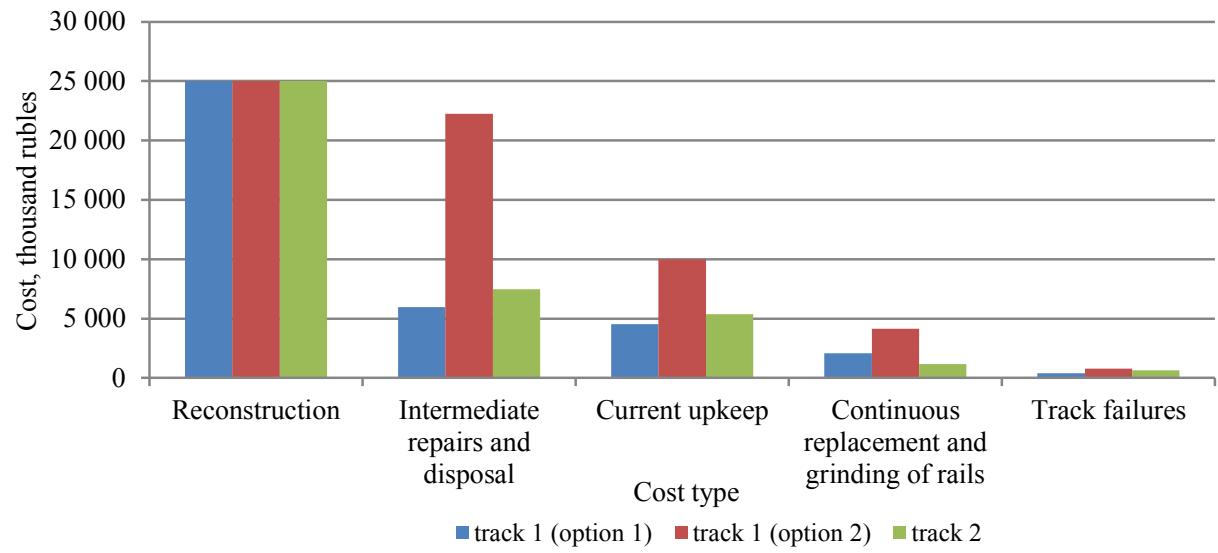

Fig. 2. Costs for maintenance and repair of $1 \mathrm{~km}$ of the railway track for the life cycle period.

As a result of the recalculation of the life cycle duration on the basis of tonnage operating units (million gross tons) per years, it was determined that the service life of the 1 track for the option 1 was 6 years; for the option 2 it was 12 years; and the life cycle of the 2 track is 20 years.

According to formula (2) and (3), the average annual cost of the life cycle and its cost for the entire service life is determined taking into consideration discount rate $d=10 \%$. See the example of calculation for the track 1 with the rated resource of 675 million gross tons (option 2).

$$
\overline{\mathrm{LCC}}=\frac{25000+5966+4520+2069+392}{6}=6325 \text { thousand rubles }
$$

With consideration of the discount:

$\mathrm{LCC}_{d}=\frac{25536}{1}+\frac{1097}{(1+0,1)^{1}}+\frac{1874}{(1+0,1)^{2}}+\frac{6526}{(1+0,1)^{3}}+\frac{1197}{(1+0,1)^{4}}+\frac{1994}{(1+0,1)^{5}}+\frac{-276}{(1+0,1)^{6}}=34884$ thousand rubles;

$$
\overline{\mathrm{LCC}}_{d}=\frac{34884}{6}=5814 \text { thousand rubles. }
$$

See the results of calculation of the LCC and $\overline{\mathrm{LCC}}$ for the rest of repair schemes in Table 3 .

Table 3. LCC calculation.

\begin{tabular}{|c|c|c|c|c|}
\hline \multirow{2}{*}{ Track } & \multicolumn{2}{|c|}{$\begin{array}{c}\text { Without consideration of the } \\
\text { discount }\end{array}$} & \multicolumn{2}{c|}{ With consideration of the discount } \\
\cline { 2 - 5 } & $\begin{array}{c}\text { LCC, thousand } \\
\text { rubles }\end{array}$ & $\begin{array}{c}\overline{\text { LCC }} \text { (LCC), } \\
\text { thousand rubles }\end{array}$ & $\begin{array}{c}\text { LCC, thousand } \\
\text { rubles }\end{array}$ & $\begin{array}{c}\overline{\text { LCC }} \text { (LCC), } \\
\text { thousand rubles }\end{array}$ \\
\hline 1 (option 1) & 37,947 & 6,325 & 34,884 & 5,814 \\
\hline 1 (option 2) & 62,169 & 5181 & 46,693 & 3,891 \\
\hline 2 & 39,650 & 1,983 & 31,254 & 1,563 \\
\hline
\end{tabular}




\section{Analysis of the results obtained}

The performed calculations for a particular section of the track showed that the largest average annual life cycle cost of the upper railway track structure is observed on the track 1 (option 1) with the repair scheme of RC B A B RC [16] (with the cycle duration of 6 years) is 5,814 thousand rubles taking into consideration the discount rate. The increase in the life cycle (up to 12 years) and the reduction of its average annual cost was achieved by continuous replacement of rails in the middle of the life cycle accompanied by the works in the scope of average track repair, as a result of which $\overline{\text { LCC }}$ (LCC) on the 1 track (2 option) was reduced to 3,891 thousand rubles. The economic effect of using such repair scheme with consideration of the discount will be

$$
\mathrm{EE}=5814-3891=1923 \text { thousand rubles per year. }
$$

The lowest life cycle cost is observed on the 2 track of the section in connection with the low axial load and low traffic density, where the repair scheme of RC B B A B L RC is applied, amounting to 1,563 thousand rubles (the life cycle duration is 20 years).

The highest share in cost elements belongs to reconstruction: $65.9 \%$ on the track 1 (option 1), $40.2 \%$ on the track 1 (option 2) and $63.1 \%$ on the track 2 . The second place is held by the costs for intermediate repairs and disposal: track 1 (option 1) $-15.7 \%$, track 1 (option 2) $-35.7 \%$, track $2-18.8 \%$. The next lower share of the costs is attributed to the current upkeep: track 1 (option 1) $-11.9 \%$, track 1 (option 2 ) $-16.1 \%$, track $2-13.5 \%$.

\section{Conclusion}

The performed research on the method of engineering and economic evaluation of the efficiency of the upper railway track structure allowed developing the method for estimating its life cycle cost, including the cost model, specific methods for determining the cost elements, and the algorithm for calculating them [14-15].

A cost model has been adopted for estimating the LCC, which includes the costs of reconstruction (modernization), current upkeep, intermediate repairs, failures expressed in train delays and the speed of their movement, utilization of the rail-grille elements in the form of the return value of the old elements at the end of their service life, which is quite compliant with the formulated problem and the purpose of the study.

Calculations using the developed methodology have shown that it is fully adequate to the real operating conditions of the track. The greatest effect on reducing the average annual life cycle cost of the URTS provides an increase in its duration due to the continuous replacement of rails with implementation of straightening of the track in the scope of an average repair (in the middle of the life cycle), as well as in the areas with low freight intensity.

\section{References}

1. V.A. Gapanovich, Zheleznodorozhnyj transport [Railway transport] 6, 26-34 (2013). (in Russian)

2. V.A. Aksenov, Izvestia Transsiba [Journal of Transsib Railway Studies] 4, 115-123 (2013). (in Russian)

3. GOST P 54505-2011. Functional safety. Risk management on railway transport (Standartinform, Moscow, 2012). (in Russian)

4. BS EN 50126-1:2017. Railway Applications. The Specification and Demonstration of Reliability, Availability, Maintainability and Safety (RAMS). Generic RAMS Process (British Standards Institution, 2017). 
5. A. Patra, RAMS and LCC in Rail Track Maintenance. Licentiate Thesis. Division of Operation and Maintenance Engineering (Lulea University of Technology, Lulea, 2009).

6. S. Kumar, A study of the rail degradation process to predict rail breaks. Licentiate Thesis, Division of Operation and Maintenance Engineering, (Lulea University of Technology, Lulea, 2006).

7. A. Wicken, W. Fleischer, H. Liesche, Eisenbahntechnische Rundschau 4, 172-182 (2002).

8. A.V. Savin, Bezballastnyj put' [Non-ballast track] (Moscow, 2017). (in Russian)

9. M.A. Egorov, Collection of scientific papers of Rostov State Transport University: Transport and logistics: innovate development in the conditions of globalization of technological and economic rrelations 3 (36), 34-51 (2016).

10. A. Zoeteman, Doctoral thesis. Railway design and maintenance from a life-cycle cost perspective: A decision-support approach, Netherlands TRAIL Research School, 2004.

11. A.M. Zamyshljaev, M.Yu. Rachkovskiy, M.S. Nikiforova, Ekonomika zheleznyh dorog [Economy of railways], 12, 11-22 (2012). (in Russian)

12. STO RZD 1.02.034-2010. Upravlenie resursami na jetapah zhiznennogo cikla, riskami i analizom nadezhnosti (URRAN). Obshhie pravila ocenki i upravlenija riskami [Resource management at life cycle stages, risks and reliability analysis (URRAN). General rules for risk assessment and management (Standartinform, Moscow, 2010). (in Russian)

13. STO RZD 1.05.509.15-2002. Sistema upravlenija jeffektivnost'ju postavok. Rukovodstvo po ocenke stoimosti zhiznennogo cikla produkcii [Supply Chain Management System. Guide to assessing the value of the life cycle of products] (Standartinform, Moscow, 2008). (in Russian)

14. N.I. Karpushhenko, A.V. Bystrov, P.S. Truhanov, Railway Track and Facilities, 1, 27 (2016). (in Russian)

15. N.I. Karpushhenko, A.V. Bystrov, P.S. Truhanov, Ekonomika zheleznyh dorog [Economy of railways], 8, 45-51 (2016). (in Russian)

16. Tehnicheskie uslovija na raboty po rekonstrukcii i remontu zheleznodorozhnogo puti [Technical conditions for work on the reconstruction and repair of the railway track]. (to be published). (in Russian) 